\title{
NOVÉ SÍDLISKOVÉ NÁLEZY Z DOBY BRONZOVEJ Z GÁNOVIEC-ZA STODOLAMI ${ }^{1}$
}

\author{
M A T Ú Š H DÁK - M ÁRI A H U DÁKOVÁ - M A R T I N H L OŽE K - \\ D O M I N I K A O R A V K I N O Á
}

\begin{abstract}
New Settlement Finds from the Bronze Age in Gánovce-Za stodolami. When it comes to Bronze Age, the archaeological site Gánovce is mainly known due to significant finds collection from the filling of a ritual well, which was excavated in the location Hrádok during the travertine exploitation. There is less information available about the settlement agglomerations, which surrounded and was connected to this locality of Central-European importance. One of them was situated in the close proximity on the eastern edge of the site Hrádok, at the location Za stodolami. Most of the archaeological finds, which were there acquired by several surface prospections during 2019-2020 can be dated to the end of Early Bronze Age and fully reflect the traditions of Otomani-Füzesabony Cultural Complex. In addition to ceramic, a significant collection of ground stone artefacts, pottery, and bone tools have been documented. Among those were idetified two fragmentary preserved moulds made of stone, which were analyzed by SEM-EDX method confirming the presence of melted metal. Thus they reliably prove the local metallurgical production, which along with the other craft activities could have significant economic meaning for the community inhabiting the surroundings of the central site Gánovce-Hrádok.
\end{abstract}

Keywords: Eastern Slovakia, Gánovce, Bronze Age, settlement, surface finds.

\section{ÚVOD}

Gánovce sú v súvislosti s dobou bronzovou, resp. otomansko-füzesabonským kultúrnym komplexom (d’alej len OFKK) trvalo zapísané do dejín archeologického bádania. Je to najmä vd’aka konštrukcii studne, ktorá bola zahíbená do centrálneho kráteru dnes už len fragmentárne dochovanej travertínovej kopy v polohe Hrádok (obr. 1: B1). Samotná studňa preskúmaná v rokoch 1955-1956 je vzácna nielen vd’aka hnutelným nálezom $\mathrm{z}$ viacerých vrstiev výplne, ktoré svedčia o jej možnom prakticko-rituálnom využití. Spolu s dubovou výdrevou je súbor nádob a ozdôb vyrobených z brezovej kôry nateraz jediným svojho druhu (Czaková 1997; Jelinek 2019; Vlček/Hájek 1963). Aj ked’ tažba, ktorá tu prebiehala od roku 1870, zničila bez možnosti spätnej rekonštrukcie akékolvvek d’alšie štruktúry, charakter sporadicky dokumentovaných nálezov z okolia kopy indikuje, že objekt bol v závere staršej doby bronzovej súčastou sídliska (Novotný/Kovalčík 1977; Soják 2000, 115; 2007b, 177).

Od poslednej štvrtiny 20. storočia sa pozornost’ bádatelov upína k susednej polohe Za stodolami, ktorej polykultúrne osídlenie systematicky narúša rozširujúca sa výstavba obce. Pre jej poznanie sú elementárne záchranné výskumy z rokov 1987-1992 pod vedením B. Novotného a M. Novotnej, ktoré podnietila nová domová zástavba (Novotný 1988; 1990; Novotný/Novotná 1991; Novotná/Novotný 1992). Bázu poznatkov osídlenia $\mathrm{v}$ tomto priestore rozšírila séria záchranných výskumov M. Sojáka z Archeologického ústavu SAV. Boli opät motivované výstavbou nových rodinných domov, futbalového ihriska či lokálnou exploatáciou černozemí. Viaceré informácie priniesla sondáž priestoru v blízkosti plochy skúmanej v predchádzajúcom období (Soják 1999; 2007b, 178). Ďalšie z artefaktov boli vo väčšej miere sústredené v medzipriestore plochy zničenej výstavbou ihriska a východne od Hrádku (obr. 1: B2; Soják 1997; 2000, 115).

Od tohto obdobia až do súčasnosti je priestor medzi futbalovým ihriskom a Hrádkom stále a v rôznej miere narúšaný pretrvávajúcou tažbou úrodných zemín miestnymi obyvatelmi, ktorí ju prenášajú do súkromných záhrad (obr. 1: B3, C, D; Soják 2001, 176; Soják/Soják/Suchý 2004, 177). V tomto smere je účelom štúdie rozbor najnovších prírastkov zozbieraných $\mathrm{v}$ mieste d’alšieho zo zásahov a ich vyhodnotenie $\mathrm{v}$ kontexte osídlenia lokality $\mathrm{v}$ dobe bronzovej.

\footnotetext{
1 Táto práca bola podporená Agentúrou na podporu výskumu a vývoja na základe zmluvy č. APVV-18-0276 „ProSlo-Prostredie a sídliskové siete mladšieho praveku na príklade vybratých období a regiónov Slovenska“, Vedeckou grantovou agentúrou VEGA „Poznanie hospodárstva a spoločnosti doby bronzovej v oblasti severne od stredného Dunaja, prostredníctvom archeologických a environmentálnych prameňov“ (1/0100/19) a Fondom Štefana Schwarza.
} 

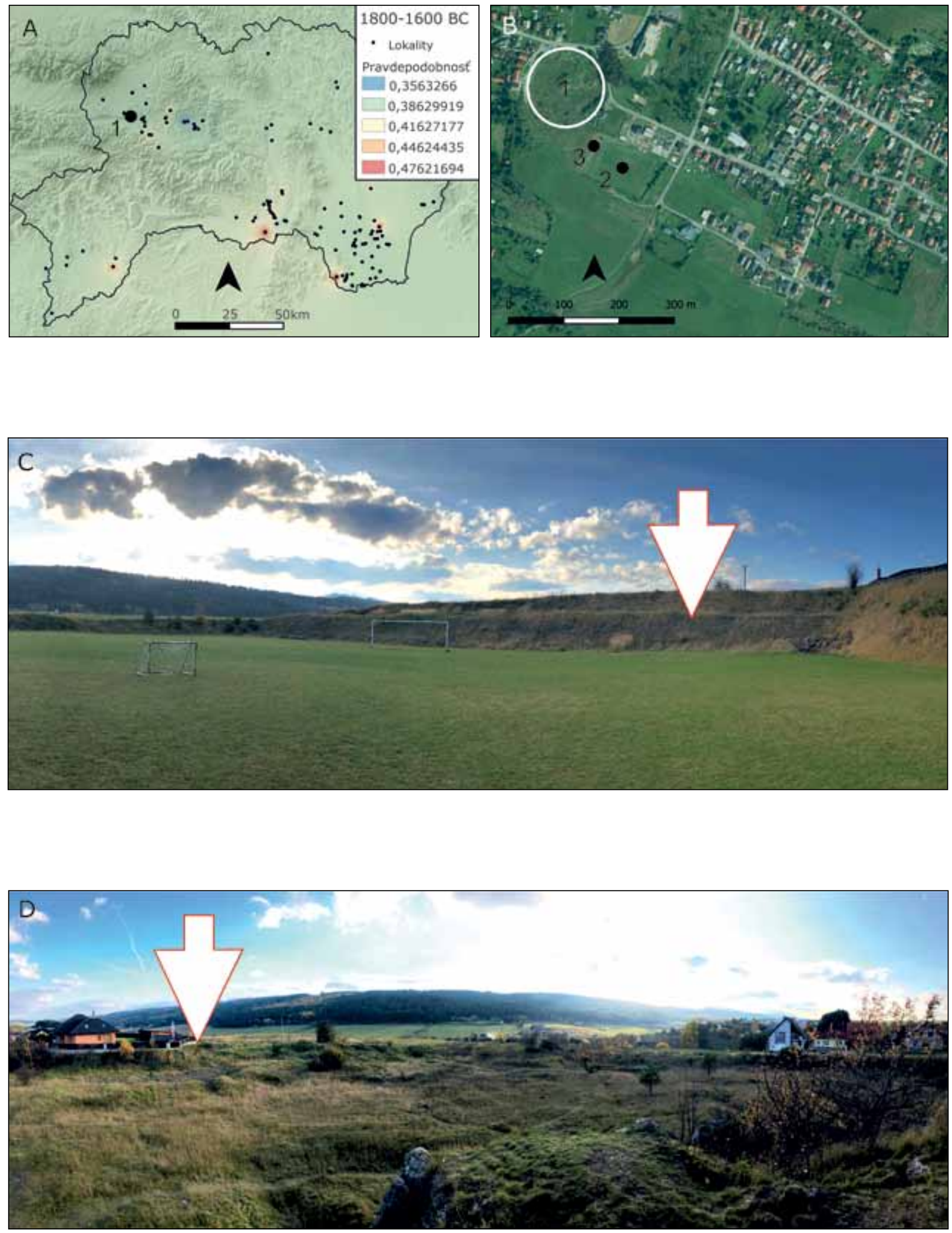

Obr. 1. Geografická lokalizácia sídliska zo staršej doby bronzovej v Gánovciach (okr. Poprad). A - mapa nálezísk OFKK z východného Slovenska osídlených v úseku 1800-1600 BC (upravené podla Tóth/Oravkinová/Pokutta 2019, obr. 4: C): 1 - Gánovce, poloha Za stodolami; B - situovanie sídliskových nálezov zo staršej doby bronzovej na južnom okraji obce Gánovce: 1 - poloha Hrádok, 2 - poloha Za stodolami, futbalové ihrisko 3 - poloha Za stodolami, medzi polohou Hrádok a futbalovým ihriskom; C - pohlad na lokáciu povrchových nálezov v polohe Za stodolami z východnej strany; D - pohlad na lokáciu povrchových nálezov v polohe Za stodolami z Gánovských travertínov (mapy a foto D. Oravkinová). 


\section{K NOVÝM ZBEROVÝM NÁLEZOM Z POLOHY ZA STODOLAMI}

Kolekcia, ktorú zozbierali pracovníci Múzea Spiša v Spišskej Novej Vsi M. Hudák a M. Hudáková počas systematických obhliadok náleziska v priebehu rokov 2019-2020, nedisponuje vzhladom na rozsah a nálezové okolnosti výraznejším interpretačným potenciálom. Napriek tomu spolu s doterajšími poznatkami dokresluje charakter minulých sídelných aktivít. Zahŕňa viacero zlomkov keramiky (105 ks, $\mathrm{z}$ toho $5 \mathrm{ks}$ sekundárne prepálených), drobných predmetov z keramiky (10 ks), artefaktov z kostí a parohu $(8 \mathrm{ks})$, kamenných nástrojov $(9 \mathrm{ks})$, jeden bronzový artefakt, fragmenty železnej trosky (12 ks), malakofaunu, zvieracie kosti a mazanicu (obr. 2; 3). Väčšinu inventáru možno s rôznou mierou pravdepodobnosti datovat' do záveru staršej doby bronzovej do OFKK, ojedinele do mladšej až neskorej doby bronzovej a mladších kultúrno-chronologických horizontov.

V keramike prevažujú zrnité až hrubozrnné nezdobené formy s hladkým (78 ks), hladeným (13 ks) a slamovaným vonkajším povrchom (14ks). Na jednom $z$ fragmentov sú viditelné odtlačky textílií (obr. 2: 2). Z typologického hladiska ich možno prisúdit’ najmä hrncom so zaobleným alebo plochým, mierne von vyhnutým okrajom, s nízkym až stlačeným mierne roztvoreným ústím, mierne baňatým až baňatým telom a rovným dnom bez alebo s miernym odsadením. Po jednom fragmente je doložené telo amfory, okraj so stenou misy so zaobleným okrajom a zatiahnutou hornou častou tela, plochý, mierne von vyhnutý okraj s ústím zásobnice, telo cedidla a miniatúrna nádobka s celozachovaným profilom. Okrem okrajov s dochovaným ústím, telom a dien s rôzne profilovanou dolnou častou tela sa našli viaceré zlomky nízkych pásikavých úch, ako aj čast' vysokého pásikavého ucha s prežliabením, ktorý mohol byṫ pôvodne súčastou džbánu. Vo výzdobe je zastúpená aplikovaná pretláčaná plastická lišta na okraji spolu s plastickými pologul'ovitými a lalokovitými výčnelkami v hornej časti vydutín (obr. 2: 5-14, 17). Hoci sa materiálové i tvarové charakteristiky nádob s funkčnými výzdobnými prvkami z gánovského súboru nevyznačujú chronologickou citlivostou, sú blízkymi derivátmi úžitkovej keramiky z opevneného sídliska z prelomu staršej a strednej doby bronzovej v Spišskom Štvrtku (Oravkinová 2018, 129-149). Po výzdobnej stránke je určujúci fragment amfory s rytými, plastickými a žliabkovanými prvkami v koncentrickej orientácii na vydutine, ktoré sú charakteristické pre keramický štýl klasickej a po- klasickej fázy OFKK (obr. 2: 1; Šteiner 2009, 64-67). Na rozdiel od neho, kompozícia výzdobných prvkov v podobe vertikálneho žliabkovania zachovaného v hornej časti tela šálky a amfory/džbánu svedčí o príslušnosti $\mathrm{k}$ mladšej fáze osídlenia $\mathrm{v}$ mladšej až neskorej dobe bronzovej lužickou kultúrou (obr. 2: 3, 4; napr. Miroššayová 1976, obr. 3: 4; 7: IV; 8: VI; Veliačik 1983, tab. XIV: 6; XXI: 16; XXV: 7).

Medzi drobnými predmetmi z keramiky dominujú sekundárne využité zlomky keramiky upravené do formy kolieska. Aj ked' sa ich funkcia interpretuje rôzne, $\mathrm{v}$ početných sériách sú nachádzané práve na sídliskách zo staršej doby bronzovej (obr. 3: 1-3; Bátora 2018, 154; Oravkinová 2018, 156-159; Šteiner 2009, 73). Na rozdiel od nich, celozachovaný praslen mohol byt๋ využitý ako zotrvačník v rámci textilnej produkcie, podobne ako štyri fragmenty závaží v tvare kužela a zrezaného štvorstenného ihlanu (obr. 3: 4-6).

Početné sú artefakty kostenej a parohovej industrie, ktoré sa morfotypologicky zvlášt neodlišujú od nálezov charakteristických pre staršiu dobu bronzovú, resp. z iných sídlisk OFKK (Oravkinovál Hromadová/Vlačiky 2017; Točík 1959). V kolekcii sa vyskytuje prstový článok s ohladením na ventrálnej strane (Sus sp.; obr. 3: 12), klinovitý nástroj vyrobený pozdĺžnym štiepaním kosti - dlátko (vel'ký cicavec; obr. 3: 9), fragment ihlice s profilovanou hlavicou vyrobený z parohu (cf. Cervus elaphus; obr. 3: 13), ako aj priečne perforovaný zvierací zub, využitelný ako závesok (Canis cf. familiaris; obr. 3: 11). Okrem hotovej ihly s uškom, ktorá je v meziálnej časti zlomená jazýčkovitým lomom (stredne vel'ký až vel'ký cicavec; obr. 3: 8) je doložený aj jej nedokončený medziprodukt - polotovar (stredný cicavec; obr. 3: 10). Špecifikom je klinovitý nástroj vyrobený pozdížnym štiepaním kla, ktorý tvarovo imituje kostené dlátko (Sus cf. scrofa; obr. 3: 7). Súčastou zbierky je fragment vetvy parohu s priečnou perforáciou obdĺžnikového alebo štvorcového tvaru, ktorá sa štandardne vyskytuje pri viacerých morfotypoch bočníc uzdy z odpovedajúceho chronologického úseku doby bronzovej (Hüttel 1981; cf. Cervus elaphus; obr. 3: 14). ${ }^{2}$

V rámci skupiny kamennej industrie sa vyskytujú bežné tvary ako ploché diskovité formy z pieskovca, ktoré mohli byt' využité ako aktívne abrazívy (obr. 3: 25, 26). V jednom fragmente sa dochoval aj zlomok platne, ktorý mohol byt vzhladom na lokálne stopy abrazívneho opotrebenia a úderových depresií použitý vo funkcii pracovnej kamennej podložky (obr. 3: 15). Zo štiepanej industrie sa našli dva limnosilicitové úštepy, jeden kortikálny, druhý s bifaciálnou retušou na distálnej hrane (obr. 3: 16, 17). Okrem

\footnotetext{
2 Za určenie druhov fauny d’akujeme Mgr. Zore Bielichovej (AÚ SAV).
} 

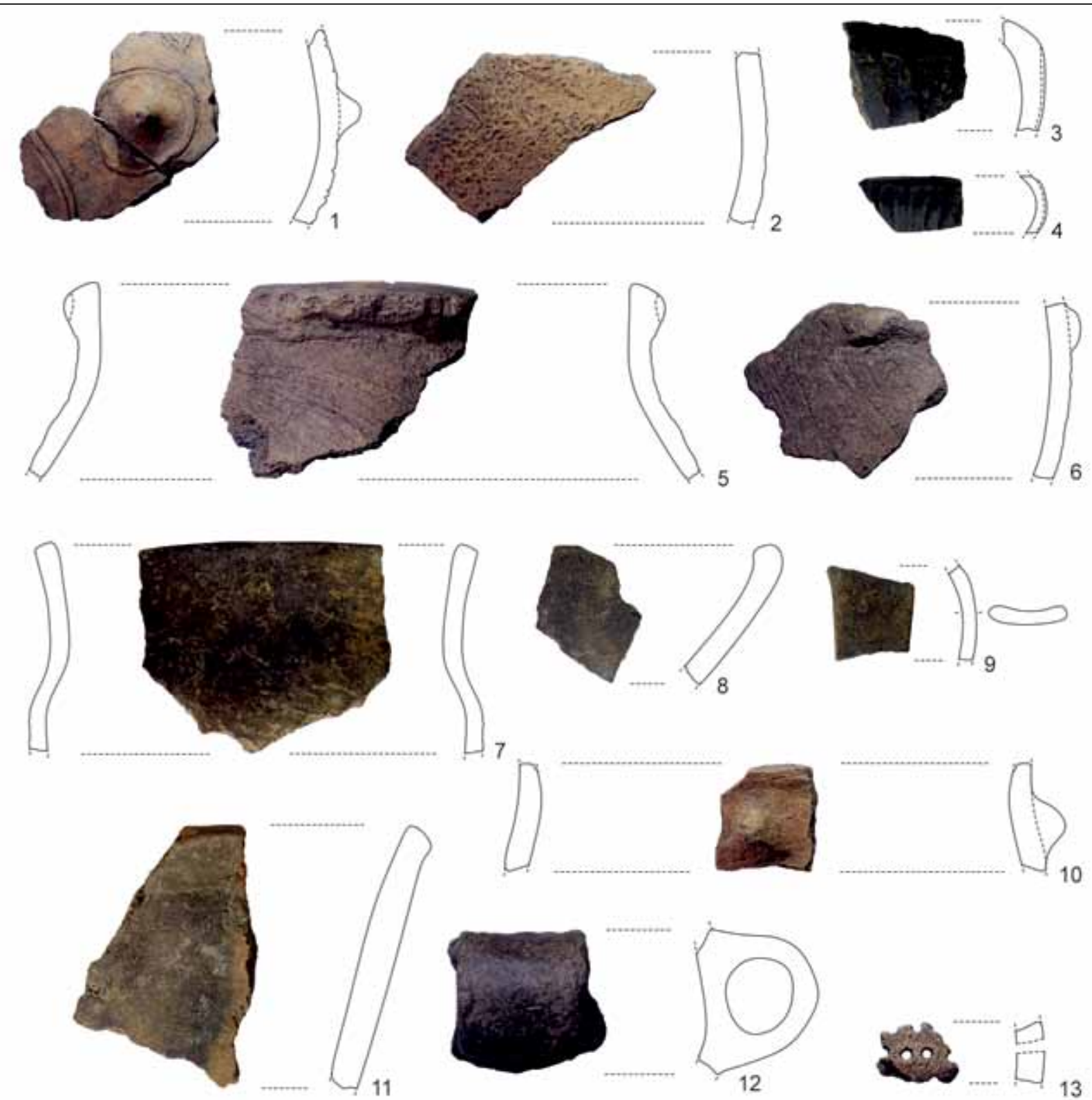

7
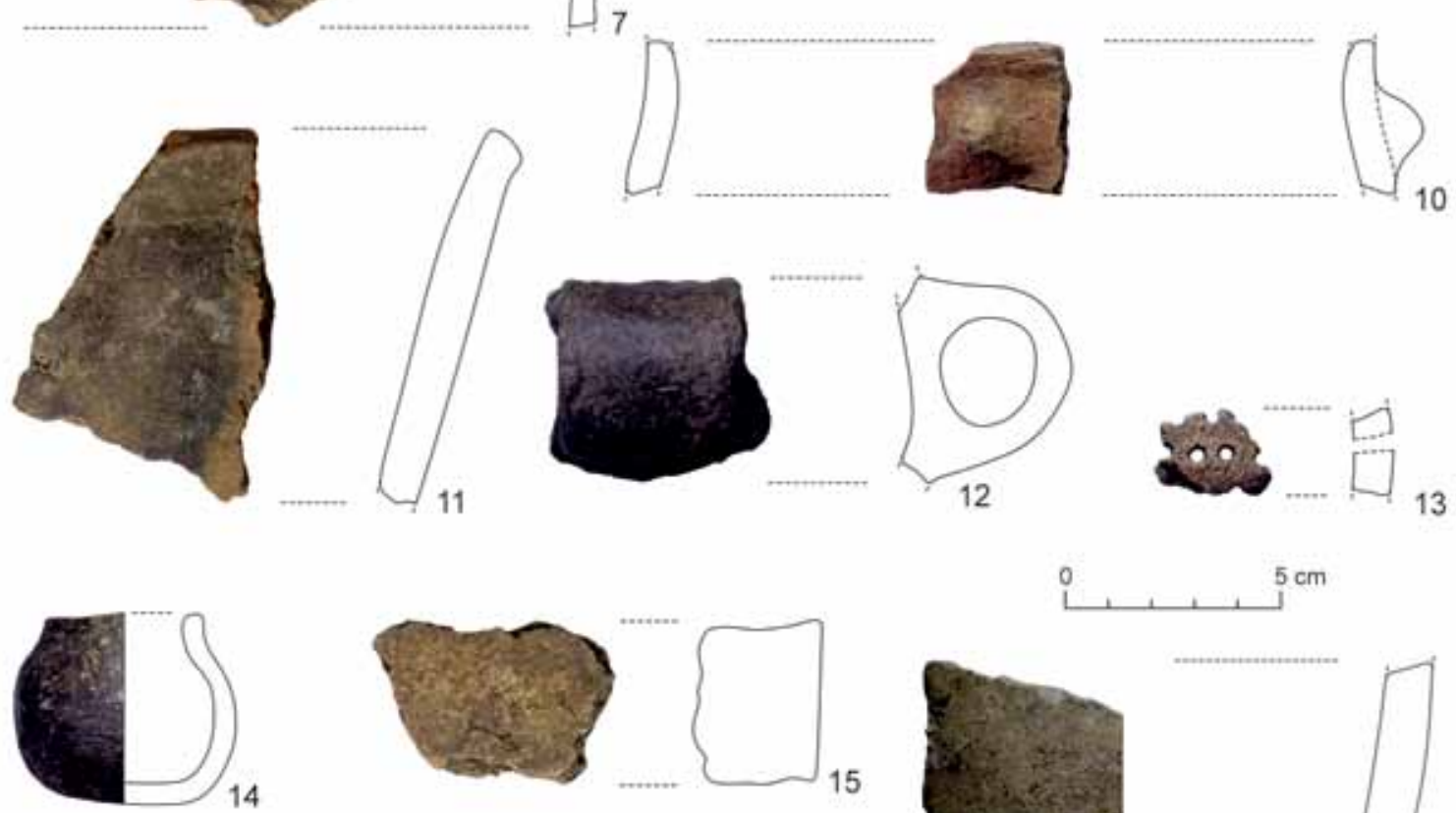

0
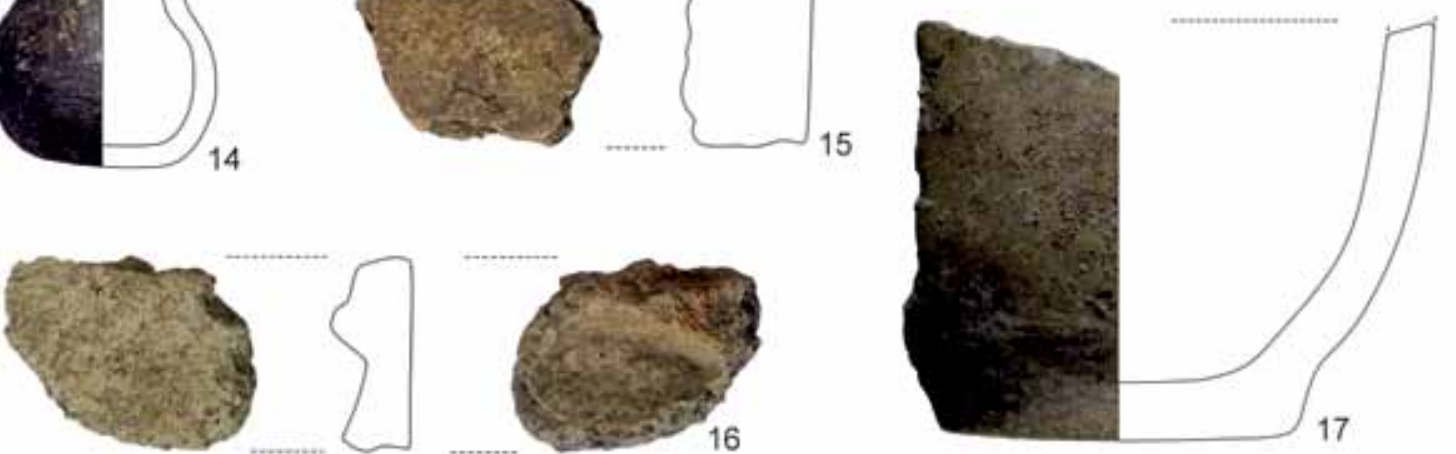

16

Obr. 2. Gánovce, poloha Za stodolami. Výber nálezov z povrchových prieskumov (foto a kresba D. Oravkinová). 


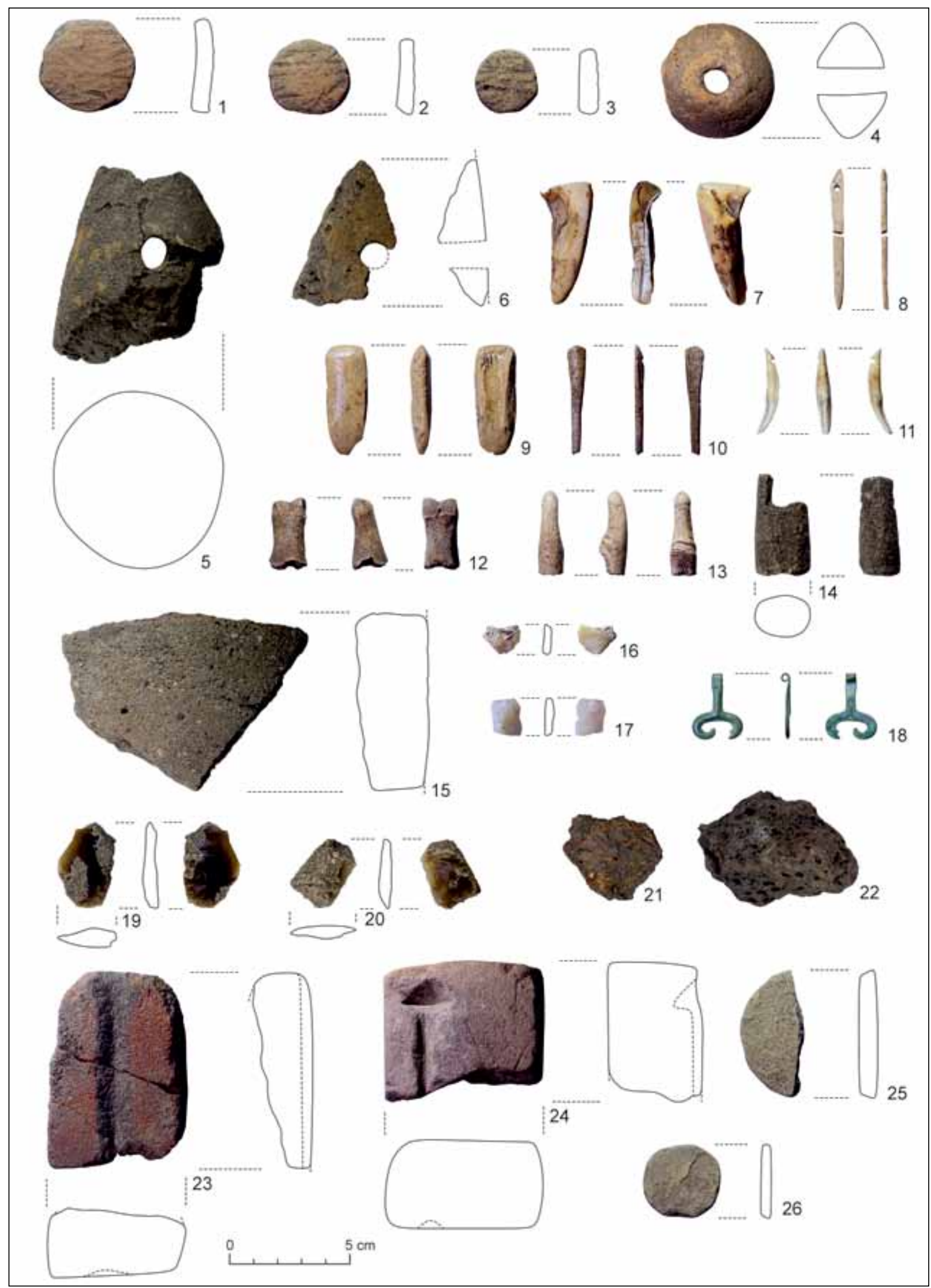

Obr. 3. Gánovce, poloha Za stodolami. Výber nálezov z povrchových prieskumov (foto a kresba D. Oravkinová). 

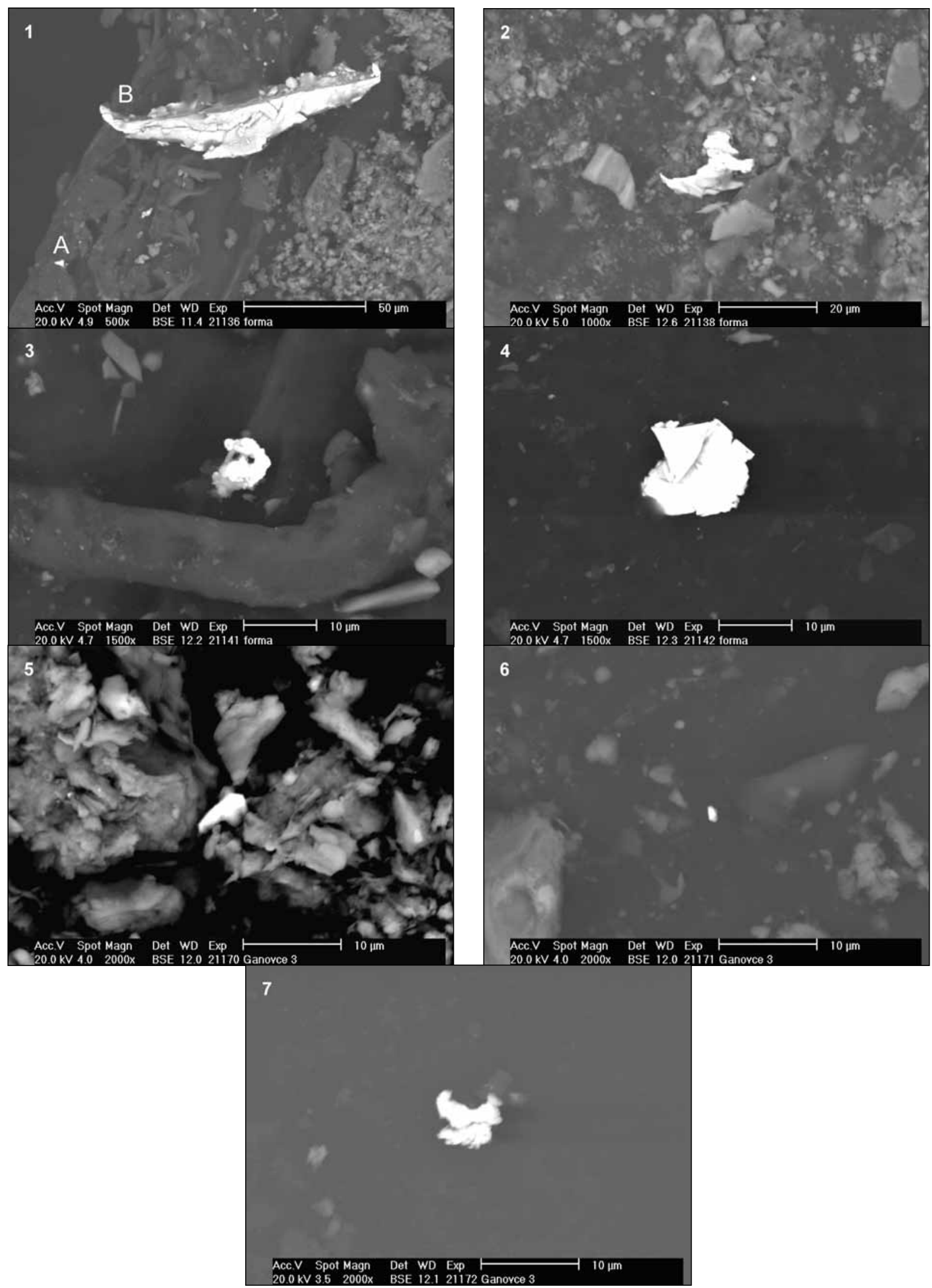

Obr. 4. Gánovce, poloha Za stodolami. SEM-EDX analýza kovových častíc z povrchu pieskovcových kadlubov. 1-4 - forma na výrobu bližšie neurčených predmetov; 5-7 - forma na výrobu ihlíc (foto M. Hložek). 
toho boli zdokumentované dva kortikálne úštepy zo silicitu glacigénnych segimentov, z ktorých jeden vykazuje makroskopické stopy po opotrebení na distálnej a meziálnej časti lavej hrany, dorzálne aj ventrálne (obr. 3: 19, 20).

$\mathrm{Z}$ artefaktov kamennej industrie je nutné vyzdvihnút fragmenty dvoch pôvodne dvojdielnych odlievacích foriem - kadlubov. Negatív sa dá spolahlivejšie morfo-typologicky stotožnit' len $\mathrm{v}$ prípade zlomku formy vyrobenej z jemne zrnitého železitého pieskovca, ktorý slúžil na výrobu špecifického typu ihlíc s dvojkónickou a šikmo perforovanou hlavicou (obr. 3: 24). Zodpovedá variantom Gajary a Megyaszó s kónickou hlavicou, ktoré sú príznačné pre mad’arovskú kultúru a OFKK. $Z$ prostredia OFKK sú na území Slovenska známe z Vel'kej Lomnice, z Košíc-Barce, či z opevneného sídliska v Spišskom Štvrtku (Novotná 1980, 43, 44, tab. 6: 262-264; Oravkinová/Vladár 2019, obr. 3: 10, 11). Nemožno opomenút kumuláciu príbuzných tvarov ihlíc $v$ širšom makroregióne úpätia Bukových vrchov v Mad’arsku, kde sa našli výhradne v hroboch na lokalitách Füzesabony-Pusztaszikszó, Hernádkak a Megyaszó (Hájek 1954, obr. 22; Köszegi 1968, tab. XXIV: 4, 5, 7; Schalk 1994, obr. 4: 3, 4).

Typologická neurčitost' druhej z foriem so zachovaným nalievacím kanálikom $\mathrm{v}$ hornej časti, ktorá bola vyrobená zo stredne zrnitého železitého pieskovca, nevylučuje v spojení so známym polykultúrnym osídlením polohy mladšie datovanie, eventuálne do strednej až neskorej doby bronzovej (obr. 3: 25). Vzhladom na kontúry prepáleného negatívu len odhadujeme, že slúžila na odlievanie polotovarových foriem, ktoré mohli byt๋ využité pri dalšom spracovaní. Tvar tyčinky zároveň evokuje nože s tyčinkovitou alebo tŕňovitou rukovätou. Hoci sa sporadicky vyskytujú od prelomu staršej a strednej doby bronzovej aj v prostredí OFKK na východnom Slovensku, k ich plnému rozmachu dochádza až v mladších kultúrno-chronologických fázach (Chebenová 2012; Oravkinová 2018, 206-208; Veliačik 2012).

Osamoteným nálezom v skupine kovovej industrie je liaty miniatúrny srdcovitý závesok bez stredového tŕńa s otvorenými ramenami (obr. 3: 18). Forma závesku sa nepovažuje za chronologicky citlivý element, ked’že najstaršie nálezy sú spájané s prostredím únětickej kultúry na juhozápadnom Slovensku. Okrem toho sa štandardne vyskytuje ako v inventároch OFKK, mad’arovskej kultúry, okruhu kultúr s inkrustovanou keramikou, tak aj následnej pilinskej kultúry a okruhu mohylových kultúr v širšej karpatskej oblasti (Furmánek 1980, 20-23; Jankovits 2017, 115-141).

Popri uvedených sa podarilo zozbierat fragmenty mazanice, $\mathrm{z}$ ktorých viaceré nesú stopy po odtlačkoch konštrukčných prvkov či lícovaní (obr. 2: 15, 16). Aj ked' ich nemožno spol'ahlivo datovat', dokladajú minulú prítomnost' sídelných architektúr.

V kontexte mladších sídelných horizontov, ktoré zistili predchádzajúce výskumné aktivity, možno železnú trosku len rámcovo priradit $\mathrm{k}$ dobe laténskej, do prelomu doby laténskej a doby rímskej, kedy bola poloha Hrádok osídlená nositel’mi púchovskej kultúry alebo do 13. storočia až novoveku (obr. 3: 21, 22; Novotný/Kovalčík 1977, 20, 21; Soják 2001, 176; Soják/Soják/Suchý 2004, 177).

\section{METÓDY A VÝSLEDKY CHEMICKÝCH ANALÝZ}

Vzorky pre chemické analýzy boli odobraté z povrchu dvoch kamenných kadlubov (obr. 4). Ked’že kvôli vel'kosti komory mikroskopu nebolo možné analyzovat' celé artefakty, prikročilo sa k lokálnemu vzorkovaniu povrchu kadlubov pomocou štvorčekov obojstrannej lepiacej pásky s vel'kostou $5 \times 5 \mathrm{~mm}$ na viacerých miestach povrchu. Eliminoval sa tak deštruktívny odber vzorky a zároveň zostal dostatok nevzorkovaných plôch pre prípadné budúce analýzy. Odobraté vzorky boli analyzované pomocou skenovacieho elektrónového mikroskopu PHILIPS XL 30 s energo-disperzným analyzátorom (SEM-EDX). Mikroanalýzy vzoriek boli vykonané na analytickom komplexe PHILIPS-EDAX. Využila sa bezštandardová analýza s dobou načítania spektra 100 sekúnd pri urýchlovacom napätí $20 \mathrm{kV}$. Práce sa uskutočnili v laboratóriách štruktúrnych a fázových analýz Fakulty strojného inžinierstva Vysokého učení technického v Brne.

Vo výsledkoch je zrejmé, že povrch odlievacích foriem nesie stopy niekol'kých farebných kovov, čím dokladá ich aktívne použitie v súdobej produkcii (tabela 1: 1-7). Chemické analýzy preukázali prítomnost' $\mathrm{Cu}, \mathrm{Sn}, \mathrm{Zn}, \mathrm{Ni}, \mathrm{Ag}$ a Pb. Prvky boli s najväčšou pravdepodobnostou súčastou bronzovej zliatiny, ktorá bola vlievaná do foriem. Ich obsah je $\mathrm{v}$ artefaktoch $\mathrm{z}$ doby bronzovej $\mathrm{v}$ karpatskom priestore pomerne bežný a $\mathrm{v}$ rámci analytických metód cielene sledovaný (napr. Liversage/Liversage 1990; Schalk 1998). Do zliatin v rôznych stopových množstvách penetrovali vd’aka chemickým vlastnostiam medených rúd, ktoré boli použité v procese hutnenia. Zvýšené hodnoty $\mathrm{Zn}$ a Pb zrejme súvisia s mierou chemickej prchavosti a ich prítomnost dokladá, že pôvodne mohli byt prítomné $\mathrm{v}$ zliatine v stopových množstvách. Rovnako takmer úplná absencia Sn nevylučuje použitie bronzoviny, ked’že vlastný povrch odlievacích foriem kontaminuje len nevýrazne (Dungworth 2000, 85; Kearns/Martinón-Torres/Rehren 2010, 54). Okrem uvedených je 
Tabela 1. Gánovce, poloha Za stodolami. Výsledky SEM-EDX analýz. 1-4-kovové častice z povrchu formy na výrobu bližšie neurčených predmetov; 5-7 - kovové častice z povrchu formy na výrobu ihlíc; 8 - srdcovitý závesok (meral M. Hložek).

\begin{tabular}{|c|c|c|c|c|c|c|c|c|c|c|c|c|c|c|c|}
\hline \multirow{2}{*}{ Meas. } & \multicolumn{10}{|c|}{ Elements Wt (\%) } \\
\cline { 2 - 14 } & $\mathbf{O}$ & $\mathbf{A l}$ & $\mathbf{S i}$ & $\mathbf{P}$ & $\mathbf{S}$ & $\mathbf{C a}$ & $\mathbf{M n}$ & $\mathbf{F e}$ & $\mathbf{N i}$ & $\mathbf{C u}$ & $\mathbf{Z n}$ & $\mathbf{A g}$ & $\mathbf{S n}$ & $\mathbf{P b}$ \\
\hline $\mathbf{1 A}$ & 6,66 & - & - & - & - & - & - & - & - & 53,93 & 37,73 & - & - & 1,68 \\
$\mathbf{1 B}$ & 9,59 & - & - & - & - & 7,41 & 4,04 & - & - & - & - & - & 78,96 & - \\
$\mathbf{2}$ & - & 0,99 & 1,42 & - & - & - & - & 97,59 & - & - & - & - & - & - \\
$\mathbf{3}$ & 4,04 & - & - & - & - & - & - & - & - & - & - & - & - & 95,96 \\
$\mathbf{4}$ & 0,08 & - & - & - & - & - & - & - & - & - & - & 98,92 & - & - \\
$\mathbf{5}$ & 9,73 & 2,54 & 3,84 & - & 8,79 & 1,22 & - & - & - & 73,87 & - & - & - & - \\
$\mathbf{6}$ & - & - & 12,05 & - & - & - & - & - & - & 87,95 & - & - & - & - \\
$\mathbf{7}$ & - & - & - & - & - & - & - & - & 12,77 & 63,21 & 24,03 & - & - & - \\
$\mathbf{8}$ & 12,36 & - & 1,27 & 0,99 & - & 2,24 & - & - & - & 72,19 & - & - & 10,95 & - \\
\hline
\end{tabular}

zaujímavá aj prítomnosť čiastočiek kovového železa. Ak vylúčime možnost', že sa jedná o kontamináciu, tak sa možno domnievat', že tieto kovové čiastočky na povrchu vznikli počas procesu odlievania. Pred odlievaním je nutné formu predhriat. Forma vystavená vysokej teplote mohla byt v priamom kontakte s dreveným uhlím a popolom, ktoré tak mohlo na povrchu použitých foriem zo železitých pieskovcov vyvolávat' vznik kovových železných čiastočiek. Pre overenie vyššie uvedených možností bude $\mathrm{v}$ budúcnosti perspektívne zhotovit' z geologicky podobných pieskovcov odlievaciu formu, vykonat' experimenty a povrch pre porovnanie analyzovat' metódou SEM-EDX.

Spolu s kamennými kadlubmi bolo identickou metódou preverené aj chemické zloženie miniatúrneho otvoreného srdcovitého závesku (obr. 3: 18). Výsledky merania plochy na zadnej strane artefaktu, ktorá bola lokálne očistená od korózie, preukazuje využívanie intencionálne legovaného cínového bronzu (tabela 1: 8).

\section{GÁNOVSKÉ TRAVERTÍNY A ICH OKOLIE V DOBE BRONZOVEJ}

Nálezy sústredené pozdíž južného okraja obce v polohách Hrádok a Za stodolami vypovedajú, že boli súčastou rozlahlejšieho areálu, ktorý bol v jednotlivých kultúrno-chronologických fázach doby bronzovej osídlovaný s rôznou intenzitou. Najstarší horizont reprezentuje torzovitý súbor keramiky zachránený počas exploatácie travertínu a z viacerých miest polohy Za stodolami, ktorý sa stotožňuje s tradíciami hatvanskej a nagyrévskej kultúry (obr. 2: 2; Novotný/Kovalčík 1977, 14, 15; Soják 1999, obr. 2: 5). Jednoznačnejšie vymedzenie staršej fázy osídlenia môže byt’ v súvislosti s aktuálnymi pozorovaniami problematické, ked’že niektoré z elementov hatvanskej kultúry pretrvávajú v náplni OFKK až do prelomu staršej a strednej doby bronzovej (Oravkinová 2018, 225, 226; Šteiner 2002).

Práve OFKK v nálezovom inventári $\mathrm{z}$ doby bronzovej preukázatelne dominuje, pričom bol identifikovaný takmer v každej z realizovaných výskumných aktivít. Kusé informácie, ktoré sú dôsledkom dlhodobých deštruktívnych zásahov, dovolujú aspoň hrubo odhadnút rozsah vtedajšieho sídliska. Koncentrácie zaznamenávame najmä z Hrádku, jeho okolia a z plochy medzi súčasným futbalovým ihriskom a zvyškami travertínovej kopy, odkial' pochádza aj zberová kolekcia. Aj ked' nateraz jediná spolahlivo preskúmaná je studňa, narušenie zahíbeného objektu sa spomína v súvislosti s exploatáciou černozemí v okolí Hrádku. Pomerne bohatý nálezový inventár, ktorý bol v tejto časti získaný, je považovaný za d’alší z nepriamych dokladov minulých štruktúr - potenciálne chát. O prítomnosti d’alšieho plytkého objektu OFKK uvažuje M. Soják aj vo vzdialenejšej polohe (Soják 1999, 46; 2000, 115; 2001, 176).

Na doteraz evidovaných fragmentoch zdobenej keramiky z džbánkov a amfor OFKK sa opakujú motívy $\mathrm{v}$ podobe rytých a žliabkovaných prvkov v horizontálnej orientácii alebo koncentricky okolo plastických aplikácií na vydutinách tiel. Zároveň sú džbánky situované na nízkych odsadených kuželovitých nôžkach (obr. 2: 1; Czaková 1997, tab. 14; 17; Novotná/Novotný 1992, obr. 38: 2, 12, 13; Novotnýl Kovalčík 1977, tab. XIV; XVI; Soják 1999, obr. 2: 2; 2001, obr. 108: 3, 7, 6). Všetky elementy zhodne svedčia o datovaní súboru keramiky, a tým aj doby osídlenia oboch polôh do klasického a poklasického horizontu OFKK, ktoré trvali od druhej polovice stupňa BA2 do BB1 podla Reineckeho (Šteiner 2009, 85-114). Je dôležité, že základný prehlad morfotypológie a výzdoby keramiky v súvislosti s úzko dendrochronologicky datovanou dubovou kon- 


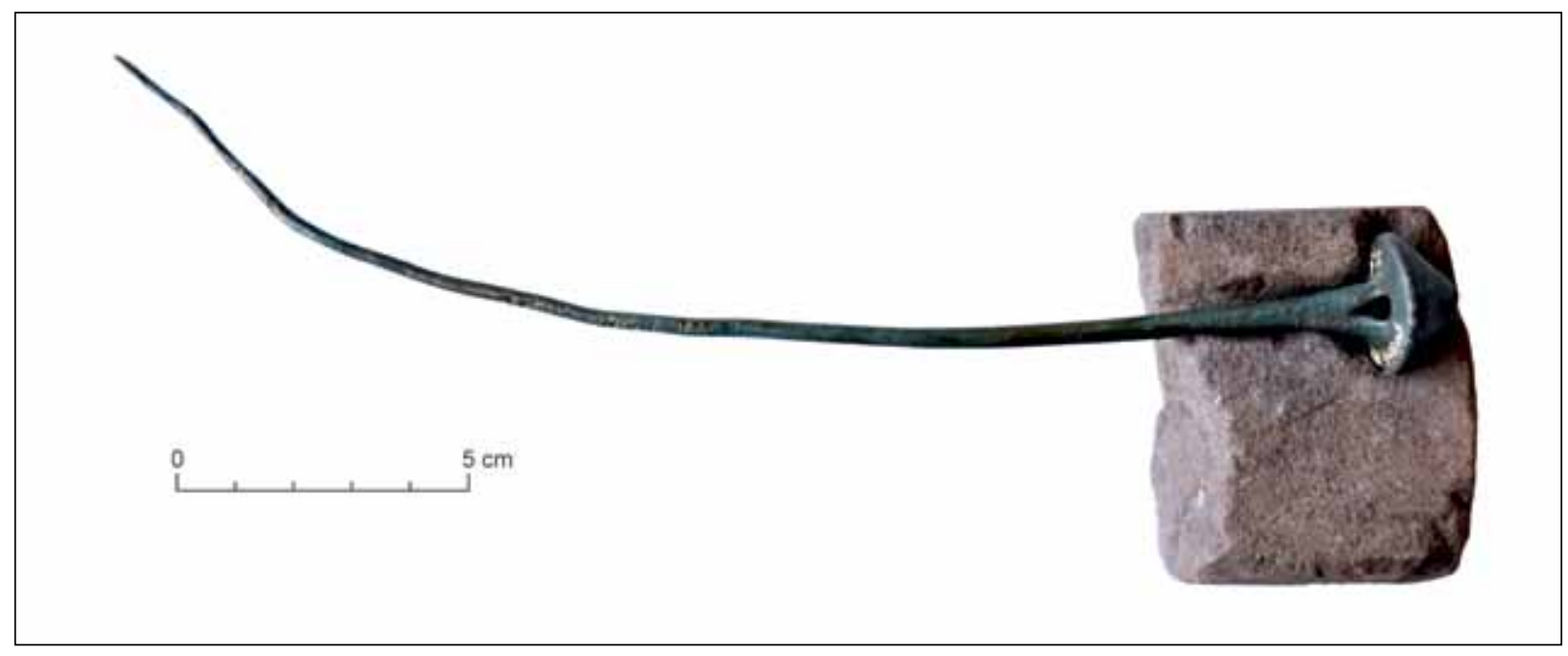

Obr. 5. Ihlica s kónickou a šikmo perforovanou hlavicou z opevneného sídliska v Spišskom Štvrtku-Myšej hôrke s korešpondujúcim kadlubom zo sídliska v Gánovciach-Za stodolami (foto D. Oravkinová).

štrukciou studne dovoluje vymedzit výskyt prvkov staršej klasickej fázy OFKK v spišskom regióne najskôr od roku 1691 denBC (Barta 2008, 244; 2017).

Spolu s keramikou možno do tohto horizontu zaradit viaceré bronzové predmety, zlatý drôtený šperk, príp. aj kosák/britvu zo železa, ktorý je predmetom diskusií (obr. 3: 18; Czaková 1997, tab. 31; Daróczi 2019; Furmánek 2007; Novotný/Kovalč́k 1977, tab. XV; Soják 2000, obr. 76: 4). Nájdený bol hrot šípu so spätnými krídelkami vyrobený z bronzového plechu, ktorý rozširuje bázu najstarších exemplárov tohto typu z opevnených sídlisk madarovskej kultúry v Budmericiach, Šuranoch-Nitrianskom Hrádku a OFKK v Nižnej Myšli (vyhodnotenie zhrnuté tu - Vavák a i. 2015, 169-173). Prítomnost' osídlenia $\mathrm{v}$ prechodnom otomansko-pilinskom horizonte nevylučuje kosák s gombíkom. V tejto súvislosti je vzácny aj starší nález sekeromlatu s kotúčovitým tylom typu B1, ktorý je na základe analógie z depotu vo Včelinciach radený do mladšej fázy kosziderského horizontu (Furmánek/Novotná 2006, 13, 14; Novotná 1970, 55, 56).

Súbor nástrojov zozbieraných v rokoch 2019-2020 s d’alšími nálezmi podobnej funkcie z výplne studne a okolia dokresluje intenzitu rôznych typov produkcií, ktoré mohli zahŕňat aktívnu textilnú, keramickú a kovolejársku výrobu, ako aj miestnu výrobu artefaktov z kosti (obr. 3: 1-10, 12, 24; Czaková 1997, tab. 22; 23; 34; 35; Novotná/Novotný 1992, obr. 38; Vlček/Hájek 1963, obr. 7). Práve aktívna výroba je parametrom súdobých opevnených sídlisk, ktorým je prisudzovaná centrálna funkcia. Pre zakladanie areálov tohto typu boli vyhl'adávané terénne vyvýšeniny a strategické plochy v dobrej dostupnosti k výmenno-obchodným trasám a ložiskám nerastných surovín (napr. Košice-
-Barca, Nižná Myšla, Rozhanovce, Spišský Štvrtok, Včelince). Travertínovú kopu Hrádok bolo možné pred založením lomu za takúto dominantu nepochybne považovat' (Novotný/Kovalč́k 1977, tab. 2; 3). Formu regionálnych interakcií sídlisk tohto druhu dokladá spolu s podobnostou materiálnej kultúry aj skutočnost', že negatív pieskovcového kadlubu z Gánoviec korešponduje s ihlicou s kónickou a šikmo perforovanou hlavicou, ktorá bola nájdená v jednom z depotov v objekte 5/68 na akropole opevneného sídliska v Spišskom Štvrtku (obr. 5; Oravkinová/Vladár 2019, obr. 3).

V chronologicky následnej strednej až neskorej dobe bronzovej sa relikty osídlenia priestorovo aj početnostou redukovali na polohu Za stodolami. Pilinskej kultúre sa pripisuje rozmerná zásobnica bez nálezov, ktorá bola preskúmaná B. Novotným počas záchranného výskumu v roku 1987 (Novotný 1988). Okrem nej bol objavený kamenný skrinkový hrob obsahujúci amforu pilinskej kultúry s nevýraznou koncentráciou uhlíkov a bronzovou ihlicou s pečatidlovou hlavicou typu Martin, ktorá je zas prvkom lužickej kultúry. Ich súčasný výskyt v hrobe poukazuje na úzku spätost̉ dvoch rôznych kultúrnych tradícií, ktorých kontaktnou zónou bol na prelome strednej a mladšej doby bronzovej práve Spiš (Novotná 1998, 36; Soják 1999, 46; 2007a, obr. 4). K horizontu mladšej doby bronzovej bez možnosti bližšej kultúrno-chronologickej klasifikácie je radený starší nález bronzovej sekerky s postranným uškom a vejárovite rozšíreným ostrím, ako aj zlomok bronzového kosáka (Furmánek/Novotná 2006, 23-25; Novotná 1970, 96, 97). Najmladšie nálezy prináležia lužickej kultúre a sú nateraz obmedzené len na keramiku, ktorú možno na základe výzdoby 
rámcovo datovat’ do stupňa HA2 (obr. 2: 3, 4; Soják/ Soják/Suchý 2004, obr. 137: 1).

\section{ZÁVER}

Dôležitost' pravekého osídlenia polôh Hrádok a Za Stodolami je zrejmá z pohladu ako historických, tak aj nedávno zozbieraných nálezov. Napriek tomu sa obom polohám s výnimkou niekol'kých vedecko-dokumentačných alebo príležitostných záchranných aktivít nedostalo pozornosti, ktorú si zasluhujú. Aj ked’ je okolie travertínovej kopy Hrádok dnes už nezvratne deštruované, výrazné relikty pravekého osídlenia sú v jej širšom okolí stále prítomné. V budúcnosti sa preto javí potrebné lokalitu konštantne kontrolovat', zabezpečit' odborný dohlad pri rozširujúcej sa výstavbe rodinných domov a súvisiacej infraštruktúry, príp. zvážit možnosti budúceho cieleného výskumu a prispiet̉ tak $\mathrm{k}$ d’alšiemu poznaniu (nielen) otomansko-füzesabonského kultúrneho komplexu na severozápadnom okraji spišskej sídelnej ekumény.

\section{LITERATÚRA}

Barta 2008 - P. Barta: Studies on absolute chronology of the Bronze Age in east-central Europe: methods and applications. Dizertačná práca. AÚ SAV. Nitra 2008. Nepublikované.

Barta 2017 - P. Barta: Radiocarbon dating of Bronze Age in Slovakia: status and perspectives. Poster. Frühbronzezeit in Mitteleuropa. Tagung der 25. internationalen Konferenz, 10.-13. 10. 2017. Mistelbach 2017.

Bátora 2018 - J. Bátora: Slovensko v staršej dobe bronzovej. Bratislava 2018.

Czaková 1997 - E. Czaková: Kultový okrsok l’udu otomanskej kultúry v Gánovciach. Diplomová práca. Katedra archeológie, FF UKF. Nitra 1997. Nepublikované.

Daróczi 2019 - T.-T. Daróczi: An Aegean type Bronze Age razor in the Eastern Carpathian Basin. Ziridava. Studia Archaeologica 33, 2019, 111-118.

Dungworth 2000 - D. Dungworth: A note on the analysis of crucibles and moulds. Historical metallurgy 34, 2000, $83-86$.

Furmánek 1980 - V. Furmánek: Die Anhänger in der Slowakei. PBF XI/3. München 1980.

Furmánek 2007 - V. Furmánek: Železný kosák z Gánoviec (K interpretácii najstaršieho železného predmetu v strednej Európe). In: M. Bekessová: Neandertálec z Gánoviec. Poprad 2007, 53-65.

Furmánek/Novotná 2006 - V. Furmánek/M. Novotná: Die Sicheln in der Slowakei. PBF XVIII/6. Stuttgart 2006.

Hájek 1954 - L. Hájek: Jižní Čechy ve starší době bronzové. Památky archeologické 45, 1954, 115-192.

Hüttel 1981 - G. H. Hüttel: Bronzezeitliche Trensen in Mittelund Osteuropa. Grundzüge und ihrer Entwicklung. PBF XVI/2. München 1981.

Chebenová 2012 - P. Chebenová: Nálezy bronzových nožov $\mathrm{z}$ doby bronzovej na území Slovenska. Slovenská archeológia 60, 2012, 1-36.

Jankovits 2017 - K. Jankovits: Die bronzezeitlichen Anhänger in Ungarn. Budapest 2017.

Jelínek 2019 - P. Jelínek: Birch Artifacts and Their Symbolism in the Otomani Culture. In: K. P. Fischl/T. L. Kienlin (eds.): Beyond Divides - The Otomani-Füzesabony Phenomenon. Current Approaches to Settlement and Burial in the North-eastern Carpathian Basin and Adjacent Areas. UPA 345. Bonn 2019, 71-81.

Kearns/Martinón-Torres/Rehren 2010 - T. Kearns/M. Martinón-Torres/T. Rehren: Metal to mould: alloy identi- fication in experimental casting moulds using XRF. Historical metallurgy 44, 2010, 48-58.

Kőszegi 1968 -F. Kőszegi: Mittelbronzezeitliches Gräberfeld in Pusztaszikszó. Acta Archaeologica Academiae Scientiarum Hungaricae 20, 1968, 101-141.

Liversage/Liversage 1990 - D. Liversage/M. Liversage: On distinguishing Materialgruppen in Early Bronze Age copper - the case of Výčapy-Opatovce. Památky archeologické 81, 1990, 466-475.

Miroššayová 1976 - E. Miroššayová: Lužické žiarové hroby zo Šváboviec. Nové obzory 18, 1976, 155-167.

Novotná 1970 - M. Novotná: Die Äxte und Beile in der Slowakei. PBF IX/3. München 1970.

Novotná 1980 - M. Novotná: Die Nadeln in der Slowakei. PBF XIII/6. München 1980.

Novotná 1998 - M. Novotná: Poprad v praveku. In: I. Chalupecký: Dejiny Popradu. Košice 1998, 23-41.

Novotná/Novotný 1992 - M. Novotná/B. Novotný: Pokračovanie výskumu v Gánovciach. AVANS 1990, 1992, 83.

Novotný 1988 - B. Novotný: Záchranný výskum v Gánovciach. AVANS 1987, 1988, 102.

Novotný 1990 - B. Novotný: Pokračovanie záchranného výskumu v Gánovciach. AVANS 1988, 1990, 129.

Novotný/Kovalčík 1977 - B. Novotný/R. M. Kovalčík: Katalóg archeologických pamiatok Spiša 2. Gánovce. Košice - Poprad 1977.

Novotný/Novotná 1991 - B. Novotný/M. Novotná: Výskum v Gánovciach. AVANS 1989, 1991, 74.

Oravkinová 2018 - D. Oravkinová: Výšinné opevnené sídlisko otomanskej kultúry v Spišskom Śtvrtku v kontexte karpatského kultúrneho vývoja. Dizertačná práca. Katedra archeológie, FiF UK - AÚ SAV. Bratislava - Nitra 2018. Nepublikované.

Oravkinová/Hromadová/Vlačiky 2017 - D. Oravkinová/ B. Hromadová/M. Vlačiky: Kostená a parohová industria z výšinného opevneného sídliska v Spišskom Štvrtku. Slovenská archeológia 65, 2017, 23-80.

Oravkinová/Vladár 2019 - D. Oravkinová/J. Vladár: The Phenomenon of Hoarding at the Fortified Settlement in Spišský Štvrtok. In: K. P. Fischl/T. L. Kienlin (eds.): Beyond Divides - The Otomani-Füzesabony Phenomenon. Current Approaches to Settlement and Burial in the Northeastern Carpathian Basin and Adjacent Areas. UPA 345. Bonn 2019, 83-119. 
Schalk 1994 - E. Schalk: Das Gräberfeld der frühbronzezeitlichen Füzesabony-Kultur bei Megyaszó, Nordost-Ungarn. Prähistorische Zeitschrift 69, 1994, 152-174.

Schalk 1998 - E. Schalk: Die Entwicklung der prähistorischen Metallurgie im nördlichen Karpatenbecken. Eine typologische und metallanalytische Untersuchung. Internationale Archäologie, Naturwissenschaft und Technologie 1. Rahden/Westfalen 1998.

Soják 1997 - M. Soják: Sídliskové nálezy z Gánoviec. AVANS 1995, 1997, 165, 166

Soják 1999 - M. Soják: Záchranný výkop v Gánovciach. Študijné zvesti AÚ SAV 33, 1999, 35-51.

Soják 2000 - M. Soják: Nálezy z prieskumov a záchranných exploatácií na Spiši. AVANS 1999, 2000, 114-120.

Soják 2001 - M. Soják: Terénny prieskum na Spiši. AVANS 2000, 2001, 175-185.

Soják 2007a - M. Soják: Stručný prierez archeologickými dejinami Gánoviec. In: M. Bekessová: Neandertálec z Gánoviec. Poprad 2007, 41-51.

Soják 2007b-M. Soják: Výskumy na východnom Slovensku. AVANS 2005, 2007, 177-183.

Soják/Soják/Suchý 2004 - M. Soják/O. Soják/A. Suchý: Záchranné výskumy na Spiši. AVANS 2003, 2004, 177-182.

Šteiner 2002 - P. Šteiner: Inokultúrne vplyvy na keramike otomanskej kultúry z Barce I. Študijné zvesti AÚ SAV 35, 2002, 149-153.

Šteiner 2009 - P. Šteiner: Keramický inventár otomansko-füzesabonyského kultúrneho komplexu vo svetle nálezov z Barce I. Nitra 2009.

Rukopis prijatý 9. 8. 2020

Translated by Dominika Oravkinová

Mgr. Matúš Hudák

Múzeum Spiša

Letná 50

SK - 05201 Spišská Nová Ves

matus.hudak23@gmail.com

Mgr. Mária Hudáková

Múzeum Spiša

Letná 50

SK - 05201 Spišská Nová Ves

m.hudakova@muzeumspisa.com
Točík 1959 - A. Točík: Parohová a kostená industria mad’arovskej kultúry na juhozápadnom Slovensku. Študijné zvesti Aú SAV 3, 1959, 23-53.

Tóth/Oravkinová/Pokutta 2019 - P. Tóth/D. Oravkinová/ D. A. Pokutta: Settlement Organisation of the Otomani-Füzesabony Cultural Complex in Slovakia. A Spatio-Temporal Modelling Study. In: K. P. Fischl/T. L. Kienlin (eds.): Beyond Divides - The Otomani-Füzesabony Phenomenon. Current Approaches to Settlement and Burial in the North-eastern Carpathian Basin and Adjacent Areas. UPA 345. Bonn 2019, 83-119.

Vavák a i. 2015 - J. Vavák/P. Jelínek/J. Hlavatá/ L. Illášová: Doklady metalurgie na opevnenom sídlisku mad’arovskej kultúry v Budmericiach. In: J. Bátora/ P. Tóth (ed.): Ked’ bronz vystriedal med'. Zborník príspevkov z XXIII. medzinárodného sympózia „Staršia doba bronzová v Čechách, na Morave a na Slovensku“. Levice 8.-11. októbra 2013. Bratislava - Nitra 2015, 157-186.

Veliačik 1983 - L. Veliačik: Die Lausitzer Kultur in der Slowakei. Nitra 1983.

Veliačik 2012 - L. Veliačik: Nože z doby bronzovej na Slovensku. Slovenská archeológia 60, 2012, 285-342.

Vlček/Hájek 1963 - E. Vlček/L. Hájek: A ritual well and the find of Early Bronze Age Iron Dagger at Gánovce near Poprad (Czechoslovakia). In: P. Bosch-Gimpera (ed.): A Pedro Bosch-Gimpera en al septuagésimo aniversario de su nacimiento. México 1963, 427-439.

Mgr. Martin Hložek, PhD.

Ústav archeologie a muzeologie, Filozofická fakulta

Masarykova univerzita

Arna Nováka 1

CZ - 60200 Brno

hlozek@phil.muni.cz

Mgr. Dominika Oravkinová, PhD.

Archeologický ústav SAV

Akademická 2

SK - 94901 Nitra

dominika.oravkinova@savba.sk 


\title{
New Settlement Finds from the Bronze Age in Gánovce-Za stodolami
}

\author{
Matú š Hudák - Mária Hudáková - Martin Hložek - \\ Dominika Oravkinová
}

SUMMARY

An archaeological locality Za stodolami situated in Gánovce was discovered in the 80s during the exploitation of chernozem causing intense destruction of the site. Those activities stimulated systematic excavation which was carried out by B. Novotný and M. Novotná from the Department of Archaeology of the Comenius University in Bratislava in coordination with Sub-Tatran Museum in Poprad. The area was later monitored by M. Soják from the Institute of Archaeology SAS for the construction of a football field and family houses. The destruction of the site has continued till the present because local inhabitants constantly exploit the residual fertile soils. Due to the terrain interventions, the area has been under control of the employees from the Museum of Spiš Territory - M. Hudák and M. Hudáková who have collected surface findings mostly dated to the turn of the Early to Middle Bronze Age.

The collection includes among others several fragments of pottery (decorated and undecorated coarseware, amphorae, pots), small ceramic finds (wheel-shaped secondary-used potsherds, spindle whorl, loom weights), artefacts made of bones and antler (phalanx with a smoothed active surface, bevelled tools made of longitudinally split bone and tusk, pin with a profiled head, transversely perforated animal tooth, needle with eye), stone tools (microlithic flakes, flat disc-shaped forms, grinding stone, moulds), bronze artefact (miniature heart-shaped pendant), malacofauna and daub. Since they come from

Fig. 1. The geographical location of the Early Bronze Age settlement in Gánovce (Poprad district). A - distribution of the OFCC sites in Eastern Slovakia in time-block 1800 - 1800 BC (modified atfer Tóth/Oravkinová/Pokutta 2019, fig. 4: C): 1 - Gánovce, site Za stodolami; B - positioning of Early Bronze Age settlement finds along the southern edge of municipality Gánovce: 1 - site Hrádok, 2 - site Za stodolami, football field, 3 - site Za stodolami, between site Hrádok and football field; $\mathrm{C}$ - view on the spot of surface finds in the site Za stodolami, from the east; D - view on the spot of surface finds in the site Za stodolami, from Gánovce travertine hill (maps and photo by D. Oravkinová).

Fig. 2. Gánovce, site Za stodolami. Section of the finds from surface collection (photo and drawing by D. Oravkinová).

Fig. 3. Gánovce, site Za stodolami. Section of the finds from surface collection (photo and drawing by D. Oravkinová). secondary contexts, spatial distribution was not taken into consideration. The objects made of hard organic materials were zoologically classified. The moulds were pethrographically examined and their surface was analysed with SEM-EDX method.

In terms of relative chronology, the findings date back to stages BA2 to BB1 after Reinecke. The source base does not deviate from the scope of material culture from other settlements of OFCC in the northeastern Carpathian Basin. Since Za stodolami is situated close to a well-known locality, Hrádok, they were obviously a part of an identical settlement layout. This is indicated by the morphotypological similarity of artefacts collected from a ritual well with the newly gained collection. Apart from pottery, it contains various types of tools which could be used in various production activities such as textile production and leather processing, working with soft or hard organic materials, pottery production, but mainly active metallurgic production. This is proved by two fragments of sandstone moulds with positive traces of melted metal. The agglomeration of Gánovce is thus getting close to co-temporary production-distribution centers, e.g. Košice-Barca, Nižná Myšla, Rozhanovce, Spišský Štvrtok, Včelince. The range of inter-site contact zones at the end of Early Bronze Age is illustrated by a mould used for casting the pins with double-conical heads, which correlates with the pin found in the fortified settlement in Spišký Štvrtok.

Fig. 4. Gánovce, site Za stodolami. SEM-EDX analysis of the particles observable on outer surface of sandstone moulds. 1-4-mould used for casting of unknown artefact; 5-7-mould used for casting of pin with conical head (photo by M. Hložek).

Fig. 5. The fitting of pin with conical head from fortified settlement in Spišský Štvrtok-Myšia hôrka with the mould from Gánovce-Za stodolami (photo by D. Oravkinová).

Table 1. Gánovce, site Za stodolami. SEM-EDX elemental composition. 1-4 - metal particles on mould surface used for casting of unknown artefacts; 5-7 - metal particles on mould surface used for casting of pin with conical head; 8 - heart-shaped pendant (measured by M. Hložek). 